\title{
Fashion Designers and National Identity: A Comparative Empirical Analysis of Chinese and Korean Fashion Designers
}

\author{
Chenhao Sun \& Jisoo $\mathrm{Ha}^{1}$ \\ ${ }^{1}$ Department of Textiles, Merchandising \& Fashion Design, College of Human Ecology, Seoul National \\ University, Korea \\ Correspondence: Jisoo Ha, Department of Textiles, Merchandising \& Fashion Design, College of Human \\ Ecology, Seoul National University, Korea. Tel: 82-2880-1453. E-mail: jisooha@snu.ac.kr
}

Received: April 19, 2019

Accepted: May 10, 2019

Online Published: July 15, 2019

doi:10.5539/ach.v11n2p75

URL: https://doi.org/10.5539/ach.v11n2p75

\begin{abstract}
The purpose of this study is to observe the similarities and differences between contemporary Chinese and Korean fashion designers in understanding the concept of national identity. To achieve this objective, the literature review and in-depth interview were conducted. The results are as follows: Firstly, the model that interprets the influence factors of designers' awareness of national identity was built. Under the social background of national identity, including governmental role, features of culture, openness of social system and the international and economic status, features of fashion and fashion designers influence on national identity expressed in designers' fashion works. Secondly, three main similarities between fashion designers' awareness have been found. The first is that both Chinese and Korean fashion designers emphasize broader regional concept about national identity; the second is that influence of national identity is subtle and not obvious; the third is that fashion designers have mixed consciousness of self-identity and national identity. Thirdly, there are three main differences between Chinese and Korean fashion designers' awareness. The first is that the adoption of ethnic national identity in fashion design is more related to the traditional ethnic elements in Chinese while modern elements were favored more by Korean. The second is that Chinese designers as a whole showed a deeper comprehension of traditional ethnic culture or philosophy than Korean designers do. The third is that more solid and positive attitude toward the government caused Chinese designers to have a more intensive civic national identity.
\end{abstract}

Keywords: national identity, civic national identity, ethnic national identity, chinese fashion designer, korean fashion designer

\section{Introduction}

The concept of national identity has existed in the field of fashion for a long time. Fashion also reflects more or less national identity via designers' adoption of national or cultural elements. In 1970s and 1980s Japanese fashion designers first appeared on the stage of Paris Fashion Week with their unique oriental philosophy and Japanese culture, gaining a steam of Japanese style in Western countries. When viewing the collections of English fashion designer Alexander McQueen, a strong taste from Victorian era could be perceived, which is due to his deep love for the historical garments of his country. Moreover, Vivienne Westwood, called the 'Godmother of Punk', also keeps exploring English classic tradition and hereby pushed the English charm to the highest position. As it were, there are innumerable links between fashion and national identity through fashion designers' creation.

In the recent runway show, it is also not difficult to see that more and more fashion designers in the world have begun to adopt their own country's elements which could represent national identity in their design works. Russian designer Gosha Rubchinskiy, with his eponymous brand, became a new force suddenly in global fashion market by assimilating Soviet Union culture in his 2017 SS collection, such as a symbolic socialist flag and the Russian national flag

Literature related to national identity involves cultural (Lee, 2016), economic (Kwon \& Chi, 2010), political (Law, 2013) and other various fields, but there is not so much specific literature which connects national identity with fashion directly. In addition, in the few current research most of which only concentrates on one country, such as Denmark (Melchior, 2010), China (Tsui, 2014), there appear to be lack of the perspective of native designers. Most of which written on Chinese and Korean fashion and national identity formation concentrate on historical or traditional dress (Clark, 2012; Gang \& Park, 2010; Jeong \& Choi, 2013; Kunz, 1996; Soh, 2011), China and Korea, 
as the two main countries of East Asia, have huge differences in the terms of state form and political institutions. For example, Korea is a typical capitalist country whose fashion follows Western countries tightly while China, as a socialist country, keeps its national or ethnic features in fashion to a great extent. It seems very essential and interesting to explore the differences between the two countries from the perspective of national identity. Therefore, not surprisingly, researcher selected China and Korea as two objects in this study.

Therefore, this research is expected to explore both Chinese and Korean fashion designers' understanding and attitudes towards national identity via in-depth interview and seek for the manifestation of national identity in modern fashion design. Furthermore, according to the comparative study between China and Korea, both of the two countries' fashion designers could get useful enlightenment of how to adopt and understand the national identity better in their works. The main question in the paper is how emerging fashion designers do perceive national identity and how national identity affects their works. And also it is to find out if there are differences between two countries. The fashion designers have been asked their awareness of national identity in terms of both civic and ethnic dimensions.

The result of this study will not only give a reference of how national identity is shown in nowadays fashion designers' works and how it affects them, but also being expected that fashion designers could get useful enlightenment of how to adopt and understand national identity better in their work for developing their fashion career in a globalized market, which is also meaningful to deepen cooperation and exchange between China and Korea. China and Korea are two significant countries located in Eastern Asia, and the development of which is also expected to be super significant to the rise of Asian fashion.

\section{Literature Review}

Nation consists of one or more ethnic groups and is based on a political entity, all ethnic groups inside share agreed legal system, public culture, economic and political life. National identity supplies individuals with a sense of who they are in a state, which could be also seen as an awareness of affiliation to the nation that gives people a sense of who they are in relation to others, or infuses them with a sense of purpose that makes them feel at home (Keane, 1994). Smith's dichotomous model is one of the classic models of national identity, which contrasts the ethnic-genealogical and the civic-territorial (Smith, 1991). Especially from comparative perspective, there seems to be a consensus regarding the distinction between 'civic' and 'ethnic' definitions of nationhood. Civic dimension emphasizes more fluid features of identity such as political rights, duties, and values, which are imagined as kinship through shared acceptance of political institutions and norms. In contrast fixed cultural makers and bloodlines characterize the ascriptive dimension of identity, which is usually referred as an ethnic dimension. To be specific, ethnic conception of national identity links membership with ancestry, nativity, religious or cultural custom. (Ha \&Jang, 2015).

In China it is until the opening of the 3rd Plenary Session of the 11th Central Committee of the Communist Party of China that changed the economic and political situation and did Chinese fashion begin its new development along with the opening up reform. In 1980s, the first generation of fashion designers made a figure in China. It was until 1993 that the establishment of China Fashion Designers' Association made fashion designers develop in a vocational way and then from 1998 to 2008 which is an important 10 years for Chinese fashion designers being active in international arena (Kim, 2014).

Compared with the early socialist ideology that affected China, Korea has been influenced by western clothing cultures under the liberal ideological trend of capitalism from the founding of the republic. Without the impact of fashion dead time, Korean fashion kept developing from the very beginning. As early as 1955 the term 'fashion designer' was adopted by Nora Noh and Korean first fashion show was held in Seoul in 1956, following with the first Korean International Fashion Week being held in 1959. Then Korean designers started to look for opportunities entering into international arena.

Except Chines flag, which is the symbol of China and reflects Chinese political and historical dignity, the adoption of some other political elements in fashion design is flexible in China of nowadays. It is clear that nowadays fashion does not reflect one's political ideology anymore, for instance, it is ridiculous to say that if a designer creates the design adopting green military uniform and being stylized in Cultural Revolution period means that he or she does support the Cultural Revolution. The political elements are only symbols and cannot be seen as political inclination in nowadays.

When refers to Chinese political suits in the history, Mao's suit or Sun Yetsan suit are still the main stream even in the 21 century and still mainly selected by Chinese national leaders or government. SE7EN became famous due to the reform of Sun Yetsan suit which is full of features of civic national identity of China at 2014 APEC (Asia-Pacific Economic Cooperation) conference (“染牌 2014 年APEC会议官方指定服装正式亮相北京[2014 
APEC Conference Uniform in Beijing by SE7EN]", 2014). And it is worth mentioning that Vivienne Tam, selected as the top 50 most beautiful people in the world by American magazine $<$ People $>$, became famous in global fashion field due to her launching collection adopting elements of Mao Zedong' suit in 1995. And 18 years later she applied political elements again in 2013 Fall/Winter New York Fashion Week, grasping the world's attention once more. Her collection was titled 'Mao Zedong Collection', which means that Long live President Mao, Long Long live President Mao (Mao zhu xi Wan Sui Wan Wan Sui). When she was asked about the concept of this collection, she said that she was interested in various political events happened nowadays, what she wanted to deliver was more than fashion itself (Huafang, 2013)

There are lots of fashion designers have attempted to make the connection between visible-symbolized culture and fashion. Media frequently report famous Chinese fashion designers who well-utilize distinct Chinese ethnic cultures. Guo Pei, as one of the outstanding representative Chinese Haute Couture designers, adopted Chinese ancient embroidery technic every time in her runway show, which delivers the extensive and profound meaning of Chinese traditional culture and also Lawrence $\mathrm{Xu}$ is famous for the combination of Chinese and western style. He used to apply western draping skills with classic and oriental designing elements. His $2015 \mathrm{Spring} / \mathrm{Summer}$ collection showed the world the magnificent and beautiful historical scroll of Chinese heritage Dunhuang. It is one of the most significant historical and cultural signs of the East, which is also a bridge between modern fashion and ancient civilization, facilitating the implementation of fashion and romance, modern and history (Guanchao, 2015)

Before the success of democratization, Korea was in a long-term dictatorship period; citizens had to follow the government's rules, ideologies or institutions without independent options. That was one of the reasons behind clothing-unification; fashion was full of political intentions during this period. Currently, in the globalized world today, the restraining force that the politic has to fashion has become weaker and weaker, and fashion has been generalized into the expression of an individual's personality. Designers adopt these political elements in their design without political intention but only to create the new fashion or express their views to social problems. Although there is also National Flag Laws in Korea, the citizens seem less sensitive and more tolerant to those designs adopting national flags elements.

In the TV program "Music Bank" held by KBS, Korean idol group Block B was dressed in reformed Korean school drill uniform. The designer referred to the pattern of Korean school drill uniform in the particular historical period and combined it with modern cutting, making the group members and audience satisfied. The 2016 Fall/Winter collection by CHARM'S delivers the emotion of military to the audience via the adoption of military-symbolized khaki color and the match of Flight jacket with sunglasses (Chun, 2016)

In most cases, Korean ethnic culture elements such as Hanbok and traditional patterns are considered by fashion designers more when they try to design for political leaders or the first lady. The new president, along with Korean first lady, visited the United States in 2017. The first lady dressed in a white coat painting with blue trees created by Korean artist Jeon Younghwan. The clothing she wore in the following days were all blue, as well as the president's tie. The color was from the Korean Presidential Palace, Blue House which is the symbol of peace, trust, success and hope. It is obvious that Korea president looks forward to the success of the Korea-America political talk (Kim, 2017)

Lie Sangbong introduced Korean traditional beauty to the world according to his 2015 Fall/Winter collection which was inspired by oriental ink. The black peony pattern on the garment is recreated via Korean traditional ink painting. He is considered the Korean fashion designer who is good at applying Korean traditional elements. In the collection all of the detailed elements are full of the designer's deep and strong emotion into the reinterpretation of Korean culture (““역시 이상봉!” 뉴욕 패션계 찬사[“It’s Lie Sang-bong!” New York fashion applauds]”, 2015)

\section{Research Method}

\subsection{Measuring Tools}

The research question was solved by conducting the in-depth and unstructured interviews, which were mainly based on fashion designers' personal designing experience and subjective opinions. The researcher gained designers' inferential comprehension to national identity by adopting a number of leading questions, the hidden relation between the national identity and the modern fashion design was then revealed.

The questionnaire consists of 2 parts based on the questions used by Tsui (2014) and Peidong (2013) in their researches. Before the essential questions, some basic demographic questions were asked, which was referred to the book < China Fashion: Conversations with Designers >, written by Christine Tsui (2014), for the reason that these demographic questions such as interviewees' age, education background, overseas experience could have 
impact on their awareness of national identity. The first part of the interview questions was centered on the background of fashion designer's brand, brand positioning and brand concept. According to the analysis of these questions, a general subconscious awareness of how fashion designers understand the concept of national identity can be found. Factors such as the reason for applying brand name in foreign language, or the original intention of setting the brand can all affect the designers' understanding of national identity. The second part was related to the awareness of civic national identity. The research borrowed some questions about the political and civic characteristics of clothing from the paper written by Sun Peidong (2013). These questions included: in which occasion could fashion be full of political features, what are the representative elements of civic national identity and how they are reflected, whether the support of fashion industry from the government can strengthen the civic national identity and so on. The third parts discussed the theme of ethnic national identity and fashion. Questions such as: what is ethnic culture, which features it has, how it was showed in nowadays fashion, which kind of ethnic culture was getting more and more popular recently and how it affected fashion design were asked. And the last part was about comprehensive questions including how designers being aware of the national identity, in which occasion do they feel the stronger national identity, how the national identity affects their designing progress and so on.

\subsection{Collection of Materials and Samples}

Interviewees are those fashion designers who have their own studios or work in the designer brand, and have been presenting both SS and FW collections during recent three years. Ultimately, totally 20 fashion designers including 10 Chinese fashion designers and 10 Korean fashion designers were selected respectively. For Chinese designers the interviews were conducted in Chinese and for Koreans in Korean. Under the agreement of the designers, their real names were utilized except one Chinese designer and two Korean designers. The Demographic characteristics of these designers are listed in Table 1.

Interviewees who were selected via the website of Shanghai Fashion Week and Seoul Fashion Week and then contact information such as email address, could be obtained via various ways. The researcher sent emails to those selected designers for participation. The methodology of convenience sampling and snowball sampling were conducted. The interview was conducted from 05th, November, 2017 to 18th, November, 2017, when Chinese fashion designers were interviewed in the first week in Beijing and Shanghai and then Korean designers were visited in the following next week in Seoul. The interview places, such as coffee shop, tea shop or designer's studio, were discussed and confirmed with interviewees before the interview started. The interview was conducted in the form of one-on-one conversation lasting one and a half hours. The unstructured interview outline was organized before the interview and interview contents could also be adjusted or enriched properly according to the situation. Before the interview, the researcher explained the letter of consent and introduction for research participation in details, which was checked strictly by $00000 \circ$ IRB (IRB No. 1710/003-014). Conversation was recorded under the agreement with interviewees.

Table 1. Demographic Characteristics of Interviewees

\begin{tabular}{|c|c|c|c|c|c|c|}
\hline & \multicolumn{3}{|c|}{ People's Republic of China } & \multicolumn{3}{|c|}{ Republic of Korea } \\
\hline & Brand & Name & Age & Brand & Name & Age \\
\hline 1 & $\begin{array}{c}\text { Doris Zhang } \\
\text { women's wear }\end{array}$ & Zhang Shangchao & 33 & $\begin{array}{l}\text { ANTIMATTER } \\
\text { casual wear }\end{array}$ & Kim Jiung & 32 \\
\hline 2 & $\begin{array}{c}\text { Ginger } \\
\text { fashion interior }\end{array}$ & Jiang Qiong & 31 & $\begin{array}{l}\text { AJO, AJOBYJO } \\
\text { casual wear }\end{array}$ & Kim Sehyung & 29 \\
\hline 3 & $\begin{array}{c}\text { Ms Zhao } \\
\text { fashion print }\end{array}$ & Zhao Yini & 31 & $\begin{array}{c}\text { CHANGSINSA } \\
\text { men/women's wear }\end{array}$ & *Fellicse & 25 \\
\hline 4 & $\begin{array}{c}\text { PRAJNA } \\
\text { men/women's wear }\end{array}$ & *Miao Yan & 57 & $\begin{array}{c}\text { EcommaE } \\
\text { women's wear }\end{array}$ & Lee Eunhee & 34 \\
\hline 5 & $\begin{array}{l}\text { Sansetiquette } \\
\text { women's wear }\end{array}$ & Li Yue & 28 & $\begin{array}{l}\text { Gain-g } \\
\text { men's wear }\end{array}$ & Kang Gilung & 26 \\
\hline 6 & $\begin{array}{l}\text { Shine Seven } \\
\text { casual wear }\end{array}$ & Mellon & 24 & $\begin{array}{l}\text { GREEDILOUS } \\
\text { women's wear }\end{array}$ & Park Younhee & 39 \\
\hline 7 & $\begin{array}{l}\text { SORSAKS } \\
\text { men's wear }\end{array}$ & Yao Yueting & 27 & $\begin{array}{c}\text { Katelogy } \\
\text { fashion accessory }\end{array}$ & Uh Kyungjin & 33 \\
\hline 8 & $\begin{array}{l}\text { Uncompleted } \\
\text { men's wear }\end{array}$ & Zhu Yin & 37 & $\begin{array}{l}\text { PALE TURQUOISE } \\
\text { women's wear }\end{array}$ & Park Lynjun & 25 \\
\hline 9 & $\begin{array}{c}\text { WU ZHI } \\
\text { fashion accessory }\end{array}$ & Chen Dandan & 28 & $\begin{array}{l}\text { SAIMI JEON } \\
\text { women's wear }\end{array}$ & Chun Saimi & 38 \\
\hline 10 & $\begin{array}{c}\mathrm{Xi} \\
\text { women's wear }\end{array}$ & He Linxi & 26 & $\begin{array}{c}\text { RE;CODE } \\
\text { women's wear }\end{array}$ & *Jaesik & 27 \\
\hline
\end{tabular}

Note: "**" indicates the designer under the false name 


\subsection{Data Analysis and Interpretation}

The in-depth interview aims to explore the fashion designers' deep understanding national identity nowadays and get useful enlightenment of the relation between national identity and fashion. For the purpose, it is necessary to figure out questions according to comprehensive observation and analyses, such as which type of national identity interviewees are aware of, what is the external reason resulting in this type of national identity, whether fashion design is affected by national identity, and how national identity is manifested in fashion design. Therefore, this research organized the recording data into texts first, and based on these edited literal data, the Grounded Theory proposed by Strauss \& Corbin (1998) was adopted.

The analysis was based on three steps which are open coding, axial coding and selective coding. Open coding is linked to the concept extraction of a line, a sentence, a paragraph or wholesome text and then develops categories or subcategories to be put in order in the course of time. Axial coding can be seen as the process of relating codes (categories and concepts) to each other, via a combination of inductive and deductive thinking. The basic framework of generic relationships is understood to include categories related to centralization phenomenon, causality, strategy, context and arbitration terms and consequences, so that it can provide a comprehensive understanding of the designers' awareness of national identity. Lastly, selective coding is the process of choosing one category to be the core category, and relating all other categories to that category. After segmenting all the materials via the opening coding methodology, 63 concepts, 29 subcategories and 13 upper categories were exported in Chinese part, while 69 concepts, 31 subcategories and 13 upper categories were exported in Korean part. And finally, four categorizations were sorted out based on the 13 upper categories, which are respectively, social background of national identity; characteristics of fashion designers; features of fashion and features of national identity on fashion. The example of the opening coding process was listed as follows in Table 2 . The final analysis result was examined under 3 scholars who are well experienced in the field and conducted related research based on Grounded Theory before so that the validity of this research could be assured.

Table 2. Example of Opening Code

\begin{tabular}{|c|c|c|c|c|c|}
\hline $\begin{array}{l}\text { NAME/ } \\
\text { BRAND }\end{array}$ & STATEMENTS & CONCEPT & $\begin{array}{c}\text { SUB- } \\
\text { CATEGORY } \\
\end{array}$ & $\begin{array}{c}\text { UPPER } \\
\text { CATEGORY } \\
\end{array}$ & $\begin{array}{c}\text { CATEGORI-Z } \\
\text { ATION }\end{array}$ \\
\hline $\begin{array}{l}\text { Zhu Yin/ } \\
\text { Completed }\end{array}$ & $\begin{array}{l}\text { A few years ago, the effect of the first } \\
\text { lady was quite strong. The Chinese style } \\
\text { garments that the first lady was dressed } \\
\text { in were said to be made by the domestic } \\
\text { fashion designer: Ma Ke, hence she got } \\
\text { super fame in China via the media. The } \\
\text { First lady favors Chinese fashion brands } \\
\text { and would like to wear them overseas. I } \\
\text { also feel very proud of it, I think it will } \\
\text { certainly affect some people to design } \\
\text { styles like this in fashion field. }\end{array}$ & $\begin{array}{l}\text { The first lady } \\
\text { promotes the } \\
\text { Chinese } \\
\text { design to } \\
\text { develop in the } \\
\text { direction of } \\
\text { adopting } \\
\text { cultural } \\
\text { elements. }\end{array}$ & $\begin{array}{l}\text { Representative } \\
\text { Support of the } \\
\text { First Lady }\end{array}$ & \multirow{2}{*}{$\begin{array}{l}\text { Governmental } \\
\text { Role }\end{array}$} & \multirow{2}{*}{$\begin{array}{c}\text { Social } \\
\text { Background of } \\
\text { National Identity }\end{array}$} \\
\hline $\begin{array}{c}\text { Li Yue/ } \\
\text { Sansetiquette }\end{array}$ & $\begin{array}{l}\text { Many clothing associations hold a } \\
\text { number of clothing competitions under } \\
\text { the government's support. If got the } \\
\text { government's support, I could } \\
\text { concentrate on my work more with little } \\
\text { pressure on financial problem. I think the } \\
\text { government should be the best choice if } \\
\text { the qualification from the government is } \\
\text { not strict. I will feel that I was supported } \\
\text { by the government, which is very } \\
\text { dependable. }\end{array}$ & $\begin{array}{l}\text { It will be less } \\
\text { stressful } \\
\text { under the } \\
\text { support of the } \\
\text { government. }\end{array}$ & $\begin{array}{l}\text { Designers Trust in } \\
\text { the Government }\end{array}$ & & \\
\hline
\end{tabular}

\section{Model for fashion designers' awareness of national identity}

Finally, the model, which explains fashion designers' awareness of national identity was built as Figure 1. It was built as the results of the data analysis and interpretation based on the interviews with designers. The social background of national identity includes governmental role, features of culture, openness of social system and international and economic status. With the help of the social background of national identity, features of fashion, characteristics of fashion designer, and features of national identity on fashion were shaped. In the whole social fashion environment, the way people enjoy fashion, the tendency that the consumers adopt culture, the designers' attitudes towards elements of national identity, as well as designers' self-identity are all direct influential factors on the designers' awareness of national identity. The features of national identity expressed in fashion were affected by social background both directly and indirectly and also reflect features of fashion, characteristics of fashion designers at the same time. 


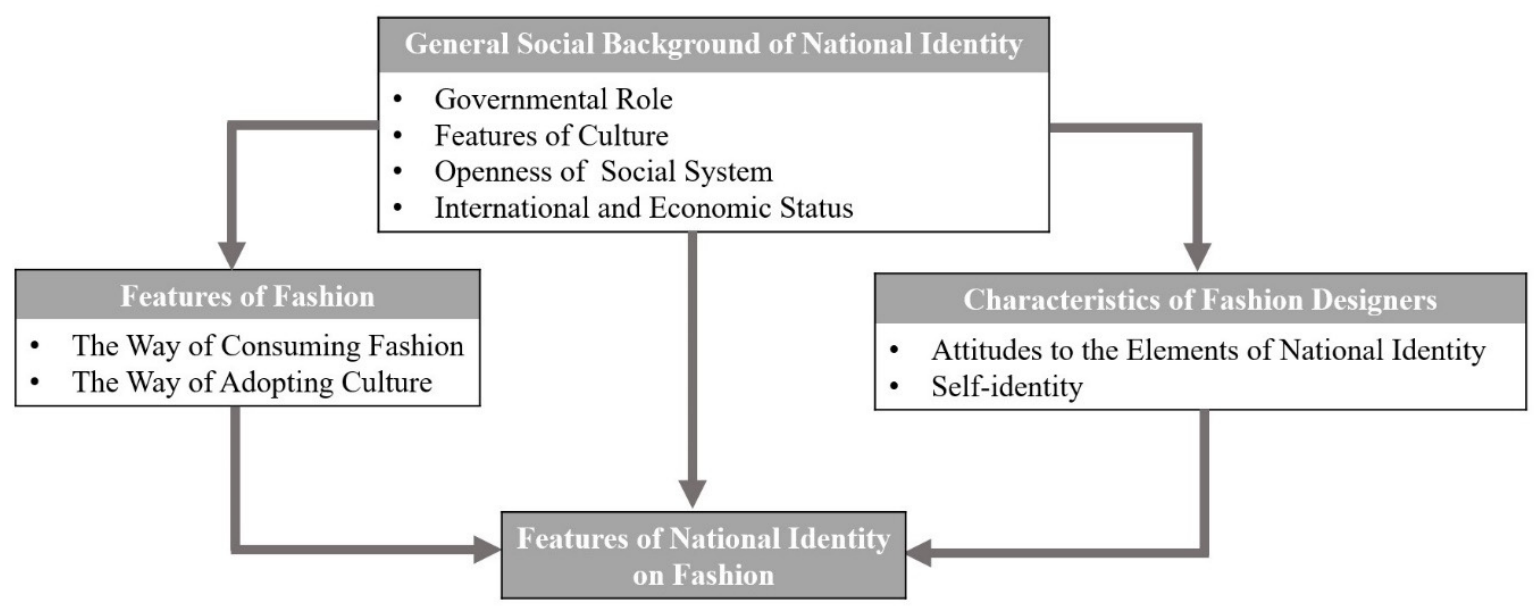

Figure 1 Model for Fashion Designers'National IdentityAwareness

The details of factors which play meaningful roles in the model have been explained as below with the interviewees' quotations.

\subsection{General Social Background}

The social background is one of the most basic factors which influence on national identity: national power corresponds to its cultural confidence; therefore, difference in national power and status of the nation is an important indicator of how confident designers from the two countries are of their nation's culture. From a societal perspective, the society's acceptance level is also a significant indicator of the strong national identity.

\subsubsection{Governmental role}

The government plays a significant role in promoting the emergence of national identity. For most designers, the Chinese government's support to both fashion and cultural industry would accelerate and enhance citizen's sense of belonging to the nation. The main stream culture that the government advocated will certainly be reflected on designers' works. Recently, the traditional cultural renaissance movement which reflects the national identity is strengthening the designers' national identity indirectly. The recognition of traditional ethnic culture, from a wider perspective, equals to the recognition to the nation.

Nowadays, the revival of Chinese traditional culture has become a cultural trend in China. What the politics did is actually promoting the cultural renaissance. The cultural renaissance advocated by the government directly leads customers'favors in the market.

Jiang Qiong, Ginger, 31

The Korean designers' trust towards the government seems to be less than that of those in China. The support for designers provided by private-owned enterprises seems to have won favor of the designers over the government. And many of designers argue that it is better to strive for the private enterprises investment so that the fashion system operation could be more effective.

I think the government's support is not as good as what the enterprise provides. As you can see, Paris or New York Fashion Week is not supported by the government but some commercial enterprises who can provide sufficient financial fund. I remember that our government provided us designers with a space to experiment once but there was nothing available at all from my point of view.

Fellicse, CHANGSINSA, 25

\subsubsection{Features of Culture}

The traditional cultural renaissance movement does not mean the rejection to western culture but a protection to ethnic culture, which could provide one more choice in people's cultural consumption. For fashion designer, the trend that the traditional culture became popular again is expected to make many designers return back to experience the traditional lifestyle, which is a process of looking for and admitting ethnic national identity. The influence from the ethnic culture is subtle. 
Nowadays, aesthetic education of traditional culture is more and more popular in our daily life. It seems that many people surrounded me begin to study traditional instrument such as Zheng or Chin compared with the western piano or guitar. Regardless of the age, Chinese people would like to go to drink a cup of tea and start to enter into this type of life full of traditional atmosphere.

Jiang Qiong, Ginger, 31

In recent years, the overall cultural characteristics of South Korea are still somewhat westernized. The interest of young people in traditional components is relatively low compared to that of China. From a societal point of view, the weakening of the traditional ethnic culture of the country to a certain extent, has slowly led to a cognitive difference between Chinese and Korean designers about the national identity.

It looks like that people in our country prefer western culture more than Korean one. I learned Taekwondo when I was a kid, but there are fewer people studying it nowadays. Instead, boxing is getting more and more popular. The traditional Korean culture has not been an obvious popularity.

Kang Gilung, Gain-g, 26

\subsubsection{Openness of Social System}

From the designer to consumer, the ability of acceptance to Chinese ethnic culture is high in the field of Chinese fashion. All of them have played a significant role in Chinese ethnic culture promotion. As a matter of fact, consuming western culture is still a mainstream although there are more and more consumers who began to favor traditional ethnic culture elements. Therefore, it seems very important for fashion designers to maintain the balance between national identity and international identity.

I launched a collection related to the Chinese 24-solar terms which widely applies digital printing patterns in the design. When we tell our consumers about the stories behind each printing, they really liked it, and the acceptance of these traditional stories or printings is much higher than I expected.

Zhang Shangchao, Doris Zhang, 33

In terms of open social system, Korea is much more favorable to the new and different culture. They tend to enjoy trying modern civilization and Americanized habit. Most of the Korean designers being interviewed had relatively negative attitude on too obviously traditional elements.

Domestic consumers do not like clothes with Korean traditional elements. When I asked the manager why they do not like them, she said the consumers seem a little bit reject Korean traditional elements and what they prefer more is modern and clean design.

Jaesik, RE;CODE, 27

\subsubsection{International and Economic Status}

The pursuit of western fashion is based on their advanced international status of science and technology. With the growth of international economic power and the rise of international standing, the national culture was gaining more attention then. Chinese ethnic culture, as a representative of showing national confidence and personality, will accelerate the ethnic national identity.

I think fashion is always the stuff behind the global economic environment. If the country was awesome, I mean, if it had strong economic strength, the world would pay close attention to it and then the culture inside, furthermore, the fashion inside.

Zhao Yini, Ms Zhao, 31

Most of the Korean designers being interviewed had a relatively low expectation to Korea's national power even though it is much stronger than ever globally. The weakness in national power or international and economic status led to their lack of confidence in their own culture, which facilitated their designs tending to reflect culture from outside more or not the national one.

I don't know whether I was a patriot or a traitor if I say that our country is not powerful anymore globally, especially recent years. There is a great gap between the rich and the poor in Korea, and so does China. However, the Korean national strength on the whole is still weak due to various reasons such as small territory. We still rely on many other countries economically, for example, the United States or China. 


\subsection{Characteristics of Fashion Designers}

The second important factor is the characteristics of fashion designers. The personal characteristics of fashion designer, including the attitudes towards traditional culture and self-identity, have a direct effect on fashion designers' awareness on national identity. How fashion designers perceive the cultural and political elements, as the most direct manifestation in clothing, will reflect how they are aware of national identity. Fashion design, as a totally privatized thing, should be considered under the effect of self-identity.

\subsubsection{Attitudes towards National Identity}

Almost all Chinese fashion designers view Chinese ethnic culture as the traditional ethnic culture only, which is due to the excellence and the diversity of Chinese culture in the history. The richness of Chinese traditional ethnic culture promotes a lot of Chinese fashion designers being favor of it, whether the visible one or the invisible one. The Chinese culture is competitive in their point of view and it is very pitiful for not being inherited.

I am so proud of our culture which is not available in other countries. It would be fairer for me to say 'competitiveness' instead of 'responsibility' when refers to Chinese culture. The transition of the layers and the gradation of colors in hand embroidery on Chinese clothing is still vivid though it has been hundred years. It is kind of a pity that such a good-looking technic could not be adopted in nowadays fashion design widely.

He Linxi, Xi, 26

Korean designers' understanding of traditional cultural elements mainly focuses on two aspects. On one hand, they feel sorry for the continuous elimination of the traditional culture and regretted the lack of Korean culture presented to the world. On the other hand, they agree that the historical trend resolved to such a cultural development and change. With the continuous infiltration of contemporary culture, more contemporary and modern trend has been set naturally and they are very essential to Korean fashion designers.

The Chinese culture left in China nowadays is something that has been filtered by the modernization. The traditional culture is various and abundant, but only few things remained at last. Korea is in the same situation and so is France. The stuff we are using now are what being selected by the era. I think the development of the traditional culture is a process being selected, being exploited, and then being developed or being eliminated.

Chun Saimi, SAIMI JEON, 38

When asked what Korean culture is, most Korean designers did not mention the traditional ethnic culture that many Chinese designers did, but concentrated on the modern lifestyle in Korea. In general, South Korean designers' feelings and emotions for the integration of modern culture in their own lives are much more significant than those of traditional culture. This is a more interesting attitude difference between China and South Korea's designers.

I don't think Korean culture is very clear or distinctive, that is why a lot of people keeps looking for what the Korean ethnic traditional culture is in recent years. However, to be honest, if we consider this question from a different angle, I think the modern culture that mixed various foreign features in our country nowadays is also an important part of Korean culture itself.

Kim Sehyung, AJO, AJOBYAJO, 29

\subsubsection{Self-identity}

As a whole, Chinese fashion designers hold a stronger sense of belonging to the nation rather than designers from other countries. A lot of Chinese designers want to let the world agree with the Chinese culture or Chinese fashion. Under this strong sense of belonging, the ethnic pride was enhanced. However, as time goes by, this sense of belonging has a tendency to become weaker and weaker.

Chinese designers really pay much attention on Chinese national identity but I think there will be fewer people acting like that in the future.

Li Yue, Sansetiquette, 28

Designers' works were seen as a carrier to promote environmental protection, and some of designers advocate to slow down the pace of production. More and more fashion designers express their attitudes through the essence of slow fashion from two perspectives: the inheritance and sustainability. The deeper human care was given to the design, and more and more Chinese and Korean were affected by these slow fashion ideologies then.

The four seasons in Shanghai is more and more indistinct compared with it when I was a child. Obviously, the result of this situation is highly linked with the destroying of the environment. Gradually, I want to remind people about such things related to environment-protecting through my design. 
I think the Korean spirit that was showed in my design is full of the feature of Jeju Island. It is future-focused, and many green, blue and silver color were adopted. I hope the beautiful environment of Jeju Island could be reserved in the future.

Park Lynjun, PALE TURQUOISE, 25

In fact, for designers from all countries, before they have achieved a high international status, they all have a certain expectation towards the development of the design industry in their own country and are eager to seek a kind of identity and recognition. This recognition will naturally strengthen the designers' national pride and promote the formation of a stronger ethnic national identity. As with China, Korean designers also feel that building such a strong national identity will take time.

When I was launching my New York collection, the most frequently asked question is "What is the house brand in Korea?" I could not figure it out, which is not because that we Korean did bad design works but for the reason that we do not have any long-established brand like the western countries have, hence we need more time to attain this goal from generation to generation. I wish in the near future, when Korean designers were asked the same question again, it will be so honorable if my brand could become that house brand.

Park Younhee, GREEDILOUS, 39

\subsection{Feature of Fashion}

The third important factor is features of fashion. Under the influence of the general influence of national identity, fashion shows two main features. First is the way people consuming fashion as cultural products or the commercial products. Second is the attitude and way to adopt traditional ethnic elements in fashion. These elements, as the typical representative of national identity, will have direct impact on the designers' awareness of national identity

\subsubsection{The Way of Consuming Fashion}

In China, fashion is not only viewed as a commercial product but also a cultural product. Many Chinese brands attempt to combine the brand itself with Chinese culture, which was seen as the carrier of delivering culture. It is good for expanding the concept of fashion, and has significant impact on delivering and developing fashion. It is the combination with the culture that attracts more designers' focusing on ethnic elements, and then their awareness of national identity will be affected.

We found that there is no suitable clothing to interpret Zen life when we advocate it. We hope to present it through clothes. With the deep development of Confucianism, Buddhism and Taoism culture in our country for so many years, it has been integrated into our lives. It is still worth being explored that how they were reflected on clothes. Our brand has done the initial attempt and has got some people's recognition.

Miao Yan, PRAJNA, 57

One of the most fundamental differences between Korean fashion and Chinese fashion is that Korea regards fashion mainly as a commercial activity. The degree of combining with culture and the government's support to cultural activities is lower than China, in Korean fashion designers' view. In the deepening consumer era, with the fast development of economy and the weakness of unsubstantial traditional culture in Korea, the support on fashion from culture has become weaker and weaker, which is the inevitable result of the industrialization.

On the forum during the Seoul Fashion Week held last year, a Chinese buyer raised a question that what can Korea fashion show to the world if it lost the support from cosmetic and idols, which I think is very important and worth considering. Of course, it is a fact that our country really did well in selling the idols or cosmetic contents in the level of VMD (Visual Merchandising), but when it refers to something just belongs to Korea fashion, it is yet to seek. Therefore, I feel a little bit pity of it.

Fellicse, CHANGSINSA, 25

\subsubsection{The Way of Adopting Traditional Culture}

Under the influence of Chinese national identity, there is an important feature of fashion which is the wide adoption of traditional elements. It shows many different characteristics based on the richness of Chinese ethnic culture. In addition to the most basic Chinese symbolized elements for example, the embroidery, more and more designers tend to be affected by the invisible-spiritual culture in order to express Chinese spiritual features. The background of fashion design which is based on the ethnic culture elements has a very important influence on the direction of the fashion designers' awareness of national identity. 
Some people may simply think that putting more embroidery on clothes means the adoption of Chinese elements, which I do not agree with. I think these designs are too superficial. It is better to determine the concept of artistic conception before designing. For example, you may feel one bag special when you first see it, and then after a while, you can feel the Zen feeling behind the bag, the adoption of Chinese culture in this bag obviously is not direct and simple. I feel we still need to dig cultural connotation deeply, and combine it subtly with the design.

Chen Dandan, WU ZHI, 28

In contrast, Korean fashion industry has taken on a more industrialized model, weakening the relation between culture and fashion, and uses more modern culture rather than traditional culture, which is in contrast with the understanding of national identity that Chinese designers have.

In fact, I would rather hide the historic background behind my design than put them in front. In comparison with traditional elements, modern culture is the more easily accepted source where I gain the inspiration.

Kim Sehyung, AJO, AJOBYAJO, 29

\section{Conclusion}

The similarities between Chinese and Korean fashion designers' awareness of national identity were examined. There are three main similarities. Firstly, with the subtle integration of Asian culture and the development of globalization, both Chinese and Korean fashion designers view national identity as a concept beyond the national boundaries. Representing or introducing Asia is a more adopted situation when they show their design works in the international stage. Oriental style, as basic cognition of Chinese and Korean fashion designers in western's view, has also accelerated the rise of Asian fashion. Meanwhile, national elements have become an alternative or not necessary in their designing processes. It is the alternative that represents an attitude that makes both Chinese and Korean fashion designers stand in a position where all the worldwide culture can be shared or communicated without prejudice. This attitude can be seen as the precondition before the emergence of the national identity concept that is beyond the national boundaries. Secondly, it is the subtle influence of national identity. The impact that national identity has on fashion designers is not obvious. An individual's background and growing environment, a country's national language and its characteristics, its national politics and its history; these accumulated factors are all permeated in the national daily life and then reflected on the individual, both in ethnic and civic perspective. It can be said that the relation between the national identity and the designer can be considered as the relation between the blood and the body. The influence of national identity is the process of the blood flowing, which leads to the run of various organs in the body. The individual's lack of the national identity directly means the lack of the most essential sense of belonging to the life. In many cases, the national identity of designers can be reflected in their work itself even though it was not in his or her intention. Lastly, it is the mixed consciousness of self-identity and national identity. Since fashion designing is very private and personal, self-identity has the most direct and intense effect on a designer's work. Self-identity that set the tone for the designer brands is actually inspired from the nation where designers are living, which could return to the national level again. Fashion designers seek to establish themselves and their brands globally, which could also be seen as a recognition process of their respective nations. As mentioned, it is often that national identity influences the designers' self-identity, and in turn affects the result of the design; therefore, from a more macro perspective, such as from the nation's point of view, self-identity and national identity are two inseparable identities. In other words, national identity, as a higher category, can only be felt in some special occasions.

The differences between Chinese and Korean fashion designers' awareness of national identity were investigated. There are three main differences. First is understanding ethnic national identity in a modern or traditional way. Under the influence of the governmental role played in traditional culture and the brand identity as well as the brand scale contained inside, Chinese fashion designers hold the opinion that ethnic national identity refers to a sense of belonging to traditional Chinese ethnic culture, which has a long and rich history. Nevertheless, from Korean fashion designers' point of view, Korean ethnic national identity is not the most representative of their national identity, the modern culture and what we are living with in this country is the most representative. This distinctive awareness results in the adoption of ethnic national identity in fashion concentrating on traditional ethnic elements more by Chinese fashion designers while modern ethnic elements were favored more by Korean fashion designers. Second is the deep or plain understanding of ethnic national identity. For Chinese fashion designers, clothing is given the meaning of inherited responsibilities especially in the dimension of the traditional ethnic culture. For most of Chinese fashion designers, it is not very difficult to interpret the relation between their design and traditional ethnic culture, in both visible and spiritual way. Contrastively, for most of Korean fashion designers, it seems different. They almost do not like to consider the inherited feature of ethnic culture in their designing progress. Most of them would not like to make some connections between their design and ethnic 
culture or traditional philosophy. Third is the strong or weak civic national identity. Korean fashion designers as a whole showed less positive attitudes towards the government in supporting fashion designer's brands compared with it in China, instead, the private enterprises seem a better choice for them. The less positive attitude to the government and institutions hence formulates a weak civic national identity in Korea in fashion designers' views. While in Chinese case, the government really plays a significant role in supporting fashion, together with the rise of Chinese international status and economic strength, these factors all help to bring about the stronger trust on Chinese government and then result in the stronger civic national identity in fashion field.

This research provides inspiration for both Chinese and Korean fashion designers in understanding Chinese and Korean fashion industry from the national identity perspective. For Korean fashion designers, it is meaningful to deepen the understanding of Chinese ethnic culture from traditional perspective and adopt appropriate Chinese ethnic elements when entering into Chinese market. For Chinese fashion designers, they are ought to focus more on modern perspective of Korean ethnic culture and rethink the core of Korean ethnic culture in order to reduce the directly-expressed ethnic feelings and better meet the requirements from the global market. As a result, it can be seen as the basic material of market strategy in order to enter in both Chinese and Korean market for fashion designers from these two countries.

As a matter of fact, the Chinese fashion industry shows some distinctive geographical features. However, due to the limited ability of the researcher and the vast territory of China, it is difficult to invite and research on a wider range of fashion designers in China. Getting the support from fashion designers from various areas in both China and Korea, or not just the only 20 designers, will bring out a more comprehensive understanding in the awareness of Chinese and Korean fashion designers in a universal way. And insufficient literature analysis seems a limitation since the study has been focused mainly on the empirical analysis. In the future study, quantitative and qualitative research are expected to be conducted together so that the result of this research can be more comprehensive and reliable.

\section{Acknowledgments}

Funded by BK 21 Plus project of the National Research Foundation of Korea Grant by the Korean Government.

\section{References}

Chun, S. J. (2016, March 24). [2016 F/W 서울패션위크] 참스, 더 새로워진 밀리터리룩[[2016 F/W Seoul Fashion Week] CHARM'S New military look]. Chosun, Retrieved on October 20, 2017, from http://fashion.chosun.com/site/data/html_dir/2016/03/24/2016032402662.html

Clark, H. (2012). Chinese fashion designers: questions of ethnicity and place in the twenty-first century. Fashion Practice, 4(1), 41-56.

Corbin, J., \& Strauss, A. (1990). Grounded Theory Research: Procedures, Canons, and Evaluative Criteria. Qualitative Sociology, 13(1), 12-15.

Gang, Z. H., \& Park, M. H. (2010). Ethnic image characteristics expressed in 21st century fashion: focus on Korean, China, and Japan. Journal of the Korean Society of Costume, 60(7), 131-142.

Guanchao Y. (2015, January 28). 中国设计师劳伦斯. 许携《敦煌》惊艳亮相巴黎高定时装周[Chinese designer Lawrence Xu's Paris Collection "Dunhuang”]. CRJ online, Retrieved on October 15, from http://gb.cri.cn/42071/2015/01/28/6891s4856859.htm

Ha, S. E., \& Jang, S. J. (2015). National identity, national pride, and happiness: the case study of South Korea. Social Indicators Research, 121(2), 471-482.

Huafang, G. (2013, March 06). Vivienne Tam 2013/14 秋冬时装秀, “毛泽东系列”[Vivienne Tam 2013/14 Fall/Winter Collection, “Mao Zedong Collection”]. 中国服装网[Chinese Fashion Internet]. Retrieved on October 13, 2017, from http://news.efu.com.cn/newsview-279228-7.html

Jeong, S. H., \& Choi, E. M. (2013). The study on the expressive characteristics of ethnic image of Korea, China, and Japan shown in modern fashion collection. Journal of Investigative Cosmetology, 9(2), 181-190. http://dx.doi.org/10.15810/jic.2013.9.2.014

Kim, S. M. (2014). A comparative study of external factors for Korean and Chinese fashion designer brand development (Unpublished master's thesis). Donghua University, Donghua.

Kunz, J. L. (1996). From Maoism to Elle: the impact of political ideology on fashion trends in China. International Sociology, 11(3), 317-335. 
Kwon, H. Y., \& Chi, E. (2010). Does national identity collide with economic interest? Public support for Northeast Asian economic integration in South Korea. Korea Observer, 41(1), 69-92.

Law, W. W. (2013). Globalization, national identity, and citizenship education: China's search for modernization and a modern Chinese citizenry. Frontiers of Education in China, 8(4), 596-627. http://dx.doi.org/10.3868/s110-002-013-0039-2

Lee, H. C. (2016). The influence of ethnic and civic national identity on attitudes toward multiculturalism: comparison of Korea, America and Japan. The Study of National Policy, 30(1), 1.

Melchior, M. R. (2010). "Doing" Danish fashion: on national identity and design practices of a small Danish fashion company. Fashion Practice, 2(1), 13-40. http://dx.doi.org/10.2752/175693810X12640026716357

Smith, A. D. (1991). National Identity. Reno: University of Nevada Press.

Soh, H. O. (2011). The People of White Clothes from Modern Perspectives. International Journal of Costume and Fashion, 11(2), 25-36.

Sun, P. D. (2013). 时尚与政治: 广东民众日常着装时尚 (1966-1976) [Fashion and politics: Chinese people of Guangdong fashion style (1966-1976)] (Unpublished doctoral dissertation). Fudan University, Zhejiang.

Tsui, C. (2013). From symbols to spirit: changing conceptions of national identity in Chinese fashion. Fashion Theory, 17(5), 579-604.

Tsui, C. (2014). Chinese Fashion: Conversations with Designers. China. Textile Publishing House

“역시 이상봉!” 뉴욕 패션계 찬사[“It's Lie Sang-bong!” New York fashion applauds]. (2015, March 02). International Textile News. Retrieved on October 21, 2017, from http://www.itnk.co.kr/news/articleView.html?idxno $=45208$

染牌 2014 年 APEC 会议官方指定服装正式亮相北京[2014 APEC Conference Uniform in Beijing by SE7EN]. (2014, November 1). Qipai. Retrieved on October 15, 2017, from http://www.qipai.com/info/news/20141101.html

\section{Copyrights}

Copyright for this article is retained by the author(s), with first publication rights granted to the journal.

This is an open-access article distributed under the terms and conditions of the Creative Commons Attribution license (http://creativecommons.org/licenses/by/4.0/). 